\title{
Walking-with Children on Blasted Landscapes
}

Karen Malone

\author{
Swinburne University of Technology, Melbourne, Australia
}

\begin{abstract}
Walking-with children on blasted landscapes opens up possibilities of an entangled set of uneasy encounters, revealing and provoking an alternative geo-storying, a de-colonialising pursuit conjured up from an awakened ethical sensibility. I am walking-with those who have been deemed unworthy of recognition and are invisible in the obscene manifestations of capitalism, the arms race, and the cold war: these companions walk with us as past ghosts as we share the horrors of a dystopian future. Walking-with children on this landscape is to bear witness to the atrocities of the Anthropocene: to bring attention to the invisible, the monsters, the unsightly possibilities, and stories of fear and fascination, doom and dread. In this paper I walk and write with the past, present, and future to highlight the complexity of what Karen Barad calls spacetimemattering.
\end{abstract}

\section{Keywords}

Children; Anthropocene; walking-with; childearth encounters; radiation; diffraction; agential realism 


\section{Walking-with}

Walking-with (Springgay \& Truman, 2018) is a time-travel-hopping (Barad, 2017) in the embodied material labour of cutting through/undoing colonialist thinking, in an attempt to come to terms with the unfathomable violence of repeated colonialisation, genocide and destruction. The trumpet plays the masculine Anthropocentric salute, while a host of onlookers have their troubling chatter silenced; teachers and UNICEF staff tell me that they will not talk of the radiation, the nuclear bombs or the polygon (Malone, 2018). Yet, in these openings of walking-with pedagogies, the childearth bodies walking-with me share haunting stories of fear, fascination and body radiation occupation.

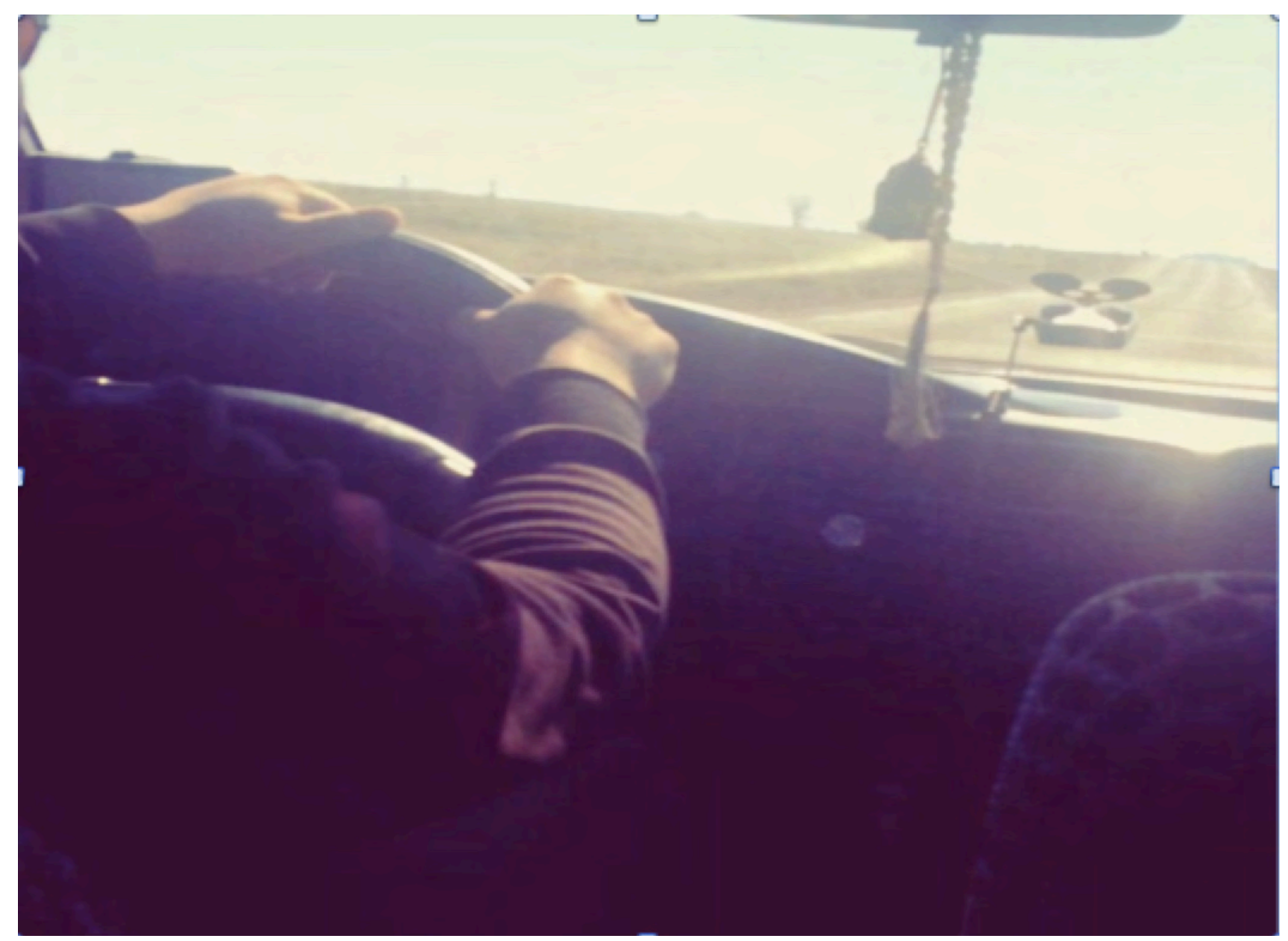

Figure 1: Across the Steppes. Photo credit: Author.

It is 2014. I am travelling to Semipalatinsk, a city on the outskirts of the Polygon nuclear test site, on the 'Steppes' in eastern Kazakhstan. After flying to Ust-Kamenogorsk, I am now traveling the 400 kilometres to Semipalatinsk via an old Russian taxi. Half-way along our journey, the driver pulls over to a dusty gas station. I decide to wander inside the small station shack to purchase some water. Once inside, I encounter a mother with a small child and a number of old men standing behind the counter. All are looking towards the back of the room. In the corner of my eye I see a man dressed in a white onesie suit and face mask. He holds an apparatus; I realise it is a Geiger counter. He motions me to come forward. I stand nervously. Sweat beads start to accumulate on my lip as the beep, beep, beep runs across my body. I close my eyes and imagine laser beams flashing on radioactive particles that are currently crashing, colliding violently and destroying delicately balanced cells, laying silent, hiding themselves deeply, dormant-the machine stops. I open my eyes. The man waves me on. I am done. I move to the door. The water can wait. A set of fear-stricken eyes are following 
my body: they belong to the young child, held closely by her mother, waiting to be scanned. As I open the door, dust sweeps across my face, particles settle deeply in my nostrils. I blow my nose.

Walking-with children on blasted landscapes means walking-with to notice, to attune to sensorial knowing, to be sweaty bodies, heavy lifting with/through the unknowing: "Walking is embodied because it is immediate, tangible, and foregrounds the bodily experience of moving" (Springgay \& Truman, 2017, p. 30). Monsters walk-with us, helping us to notice landscapes of entanglement: bodies with other bodies, time with other times (Tsing, Swanson, Gans \& Bubandt, 2017). Children take me walking-with on toxic, blasted, irradiated landscapes: "as we walk we are 'in' the world, integrating body and space coextensively" (Springgay \& Truman, 2017, p. 30). Afterwards, I write: children recognise the fragility and porosity of human and non-human life, and its link to the contaminated earth. Kazakh Indigenous and settler children walking on landscapes speak of dust, dirt, thick uneasy air, and toxic radiation. Walking-with children allows for deep, relational knowing. We talk through, with and being in place. Place-walking becomes our shared rhythm. The children bring me into their place. We take some photographs. I allow some words to resonate, turning over and over: sometime later, I re-turn to them when I am alone and write them down. I concentrate on being present, a co-presence of beings-in-common: children worlding with the ignorant unknowing stranger, Donna Haraway's 'modest witness.'

Historically, the territory of Kazakhstan was mostly inhabited by nomads. The imaginary of the nomadic body is one of being unlocatable, always moving with, and entangled in, the weathering landscape (Wuthnow, 2002). Until the sixteenth century, the nomadic Kazakhs had evolved as three jüz or territories but after repeated colonization, genocide and apartheid — as shared with similar storying of Indigeneity around the world—-the Kazakh nomad was captured by external powers who were sent to colonise the 'empty' spaces. By the mideighteenth century, in order to fend off the threatening Kokand Khanate, and facing encroachment from Tsarist Russia to the north and advancing Chinese armies in the east, the Kazakhs accepted Russian 'protection' in 1822. By the mid-nineteenth century, all of Kazakhstan was subsumed within the Russian Empire. Following the Russian Revolution of 1917, and subsequent civil war, the territory of Kazakhstan was reorganised several times before becoming the Kazakh Soviet Socialist Republic in 1936. During the 1930s and 1940s, Kazakhstan experienced population inflows of millions of exiled humans from the Soviet Union. Deportees were interned in large labour camps, many of which were in the region of Ust-Kamenogorsk and Semipalatinsk. In 1947, two years after the Second World War ended, the Soviet Union's main nuclear weapon test site, the Semipalatinsk Test Site, was founded near the city of Semey. Over 460 atomic bombs were detonated at this site over a 40 -year time frame. Following the dissolution of the Soviet Union, Kazakhstan declared independence on the $16^{\text {th }}$ December 1991. At the time of the Soviet Union's collapse, only $40 \%$ of the population was Indigenous Kazakh. The Kazakh language had all but been abandoned. Most Kazakhs were living in poverty and desperation in regional towns due to the expansive Russian industries and mining that scarred the landscape, and spread toxic chemicals on the earth and atmosphere. Independence also meant Kazakhstan inherited 1410 nuclear warheads and the highly contentious Semipalatinsk nuclear weapon testing site. By April 1995, Kazakhstan had repatriated its nuclear warhead inventory back to Russia and, by July 2000, had destroyed the nuclear testing infrastructure at Semipalatinsk. During a 50-year period, millions of adults, children, animals and birds had been exposed to high levels of nuclear radiation and radioactive pollution. 
To attend to, and be affected by, uneasy childearth encounters through walking in the streets of Semipalatinsk is to recognise the porosity of matter, radiation, pesticides and heavy metal in our waters, dust, air and bodies: playgrounds of unknown possibilities, as everyday catastrophic encounters that have been, and continue to be, the monsters walking-with us.

Walking-with our shared bodies on flat, dirty, dusty, earthy streets, Anna remarks: "I love mountains because there are no mountains in our city. I love nature and animals. I would like to walk in the mountains, which would be interesting. And I would want to dance because of being happy to be walking, and breathing fresh air, and away from the radiation of the polygon."

The theoretical frame informing this walking emerges from the unravelling of an ontology of human exceptionalism, the 'western capitalist human story' of mastery and manipulation of particles that now lay scattered across the thin skin of the landscape, re-turning in temporal diffractive reconstructions. Single particles coexist in different spacetimes. As a troubling, relational ontology, the notion of the posthuman disrupts a persistent 'humanist' paradigm by allowing new conversations to emerge. Where were we, you might ask, while the military, corporations and machines metastasised into monstrous creatures of capitalism, and at what point did we ignore/become deaf to the clarion call of the Anthropocene? There has been critique from many in regard to the naming of the Anthropocene because of its universalist nature. Universalism produces an assumption that we (humans/nonhumans) are all in this equally together. This universalizing of the human predicament neglects to acknowledge the ways in which wealth, nationality, ethnicity, gender, class, age, location and so on, mediate our relationships with the planet. As a disrupting, diffractive ontological tool, posthumanism has the potential to reveal there is no homogenous/universal species and the scale and impact of ecological damage is always unequal, unethical and unjust; Indigenous colonised peoples, woman, children, and the other-than-human species we share this planet with are in it more than those entrenched in dominant western white masculine cultures.

As a diffractive theoretical thread, this walking-with children brings the past, the present and the future together as encounters with the ruinations of a precarious monstrous planet (Barad, 2017b; Tsing et al., 2017). Seductive simplifications of industrial production have rendered most blind to monstrosity in all its forms by covering over both lively and destructive connections. They bury once-vibrant rivers under urban concrete. Radiation particles settle, nurtured, flourishing in the warmth of growing bodies. Capitalism obscures increasing inequalities beneath discourses of freedom and personal response-ability. Somehow, in the midst of these ruins, the children and I walk with earthly assemblages, rocks, dust, radiation, water and porous bodies maintaining curiosity, noticing the strange and wonderful as well as the terrible and terrifying. The geo-storying of assemblages with ethnographic attentiveness - products of the modernist, capitalist projects — offer starting points for such curiosity, along with vernacular and Indigenous knowledge practices and approaches: a pedagogical practice of everyday life (Sandlin, O’Malley \& Burdick, 2011), a walking-with openness, circulating within sites of education, domesticity and publics, shops, schools, vegetable trolleys, dogs, dirt, trucks and child bodies all mangled together. Such curiosity means working against singular notions of modernity. While walking, I memorise the many questions that situate themselves in my body-I want to revisit these later. While walking, I ask one child to explain to me what the large steel piping is that I see weaving its way through the streets. 


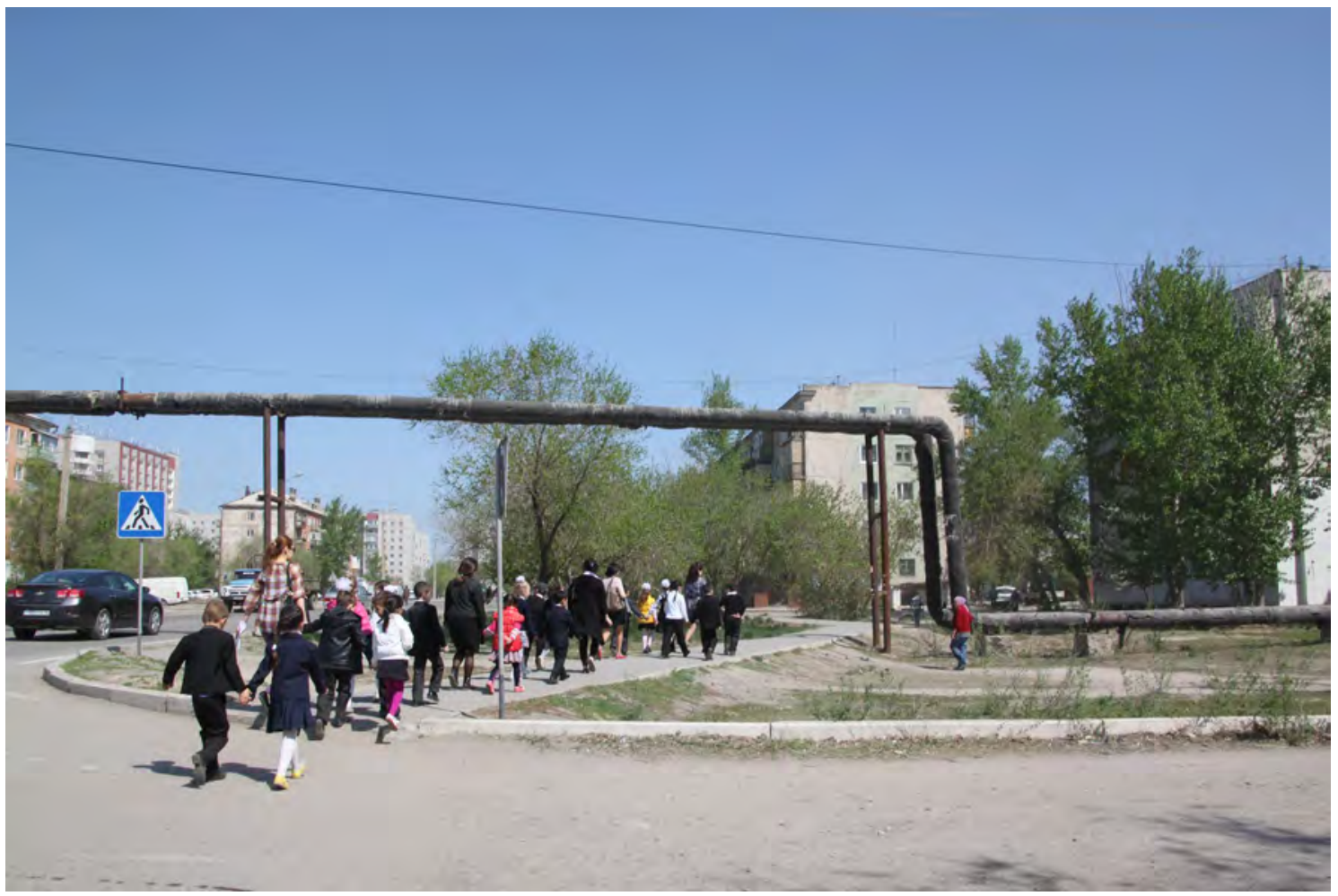

Figure 2: Walking and weaving its way. Photo credit: Author.

"That is the hot water," Yuliya tells me. "Inside the pipe is very hot steaming water that warms our houses. Once the pipe burst and people were burnt badly. I have seen hot steaming water flood down the street, and I had to jump out of the way. It melted holes in the snow."

Snow, ice, steaming water, melting streets: the materiality of harsh winters on the edge of Siberia. How can we repurpose the tools of modernity, I wonder, against the terrors of progress to make visible other worlds: damaged worlds that are ignored? Living in a time of planetary catastrophe thus begins with practices of humility and difficulty: storying worlds around us. "Storytelling," write van Dooren and Rose (2016), "is one of the great arts of witness, and in these difficult times telling lively stories is a deeply committed project, one of engaging with the multitudes of others in their noisy, fleshy living and dying. It is the aim of lively ethnographies to seize our relational imagination" (p. 94).

Our monsters and ghosts help us notice landscapes of entanglement, bodies with other bodies, time with other times (Tsing et al., 2017). The Kazakh government struggles to balance its desire to be seen as a country that is anti-nuclear, yet it has some of the largest uranium mining sites in the world: the pull and desires of economic security while worlding with others as victims of colonial exploitation. A UNICEF colleague tells me, "the reason the government wants to erase this issue of the past radiation is because Kazakhstan wants to sell more uranium to the global marketplace. We have plenty of uranium here. We are not allowed to sell much, there are certain limits."

But what is the scale of time, time-scales in irradiated worlds?

When the cascading energies of the nuclei that were split in an atomic bomb explosion live on in the interior and exterior of collective and individual bodies resetting decay times of cellular clocks, how can anything like a fixed, singular, and external notion of time retain its relevance or even its meaning? (Barad, 2017b, p. 63) 
Walking-with children seduces me into these entangled temporal possibilities: Plutonium239 has a 25,000-year half-life.

In a flash, past bodies living in the immediate vicinity of the Polygon-the site of over 450 atomic bomb detonations - ingest radioactive isotopes that indefinitely rework body molecules, all the while manufacturing future cancers, like little time bombs (Barad, 2017b): walking-with children is to be waiting-with bombs to go off. What constitutes the event of an atomic bomb that explodes at one moment then over time continues to go off in bodies of kin?

Barad's (2017b) paper Troubling Timels and ecologies of nothingness engages with my thoughts. Her words resonate over and over in my thinking; she walks with us. "The temporality of radiation exposure is not one of immediacy; or rather, it reworks this notion," which must then "rework calculations of how to understand what comes before and after, while thinking generationally" (Barad, 2017b, p. 63). Barad's thinking sings in my thoughts as I re-turn to her paper, running it over and over, attending to the liveliness of radiation and how it disrupts all concepts of time and temporality: “... radioactivity inhabits time-beings and resynchronises and reconfigures temporalities/spacetimematterings" (Barad, 2017b, p. 63). Walking-with children on/through irradiated landscapes: time in this messy, entangled space is unstable: "Radioactive decay elongates, disperses, and exponentially frays time's coherence." Time, in this walking-with children, is always in the process of "leaking away from itself" (Barad, 2017b, p. 63).

Plutonium, a heavy metal, emits alpha radiation, and the material is most harmful when inhaled or ingested. There are 'hot sites' where residual radiation is still present in the earth. On the testing site, scientists find high levels of plutonium in horse bones. Kazakh shepherds use bones to make soup. Horse soup and horse milk flows warmly on cold nights through small bodies (Malone, 2018). Aytem stops walking to introduce me to his neighbour, a kindly older woman who works at the local fruit shop.

"She is my friend. She is old, but she often makes me Kumis (fermented horse milk) to help me sleep." Aytem lives on the 10th floor of an apartment block. In later workshops he brings a photograph looking from his apartment window. He never leaves the apartment when his parents aren't there to play alone. He worries about the dirt and dust in the playground. He said it scares him he might become sick. He arrives to the workshops, and when we walk today, in a neatly pressed formal suit. He tells me his parents have told him it is important to use this opportunity to give his point of view because we are important government people. He speaks often and with confidence.

Karin Murris (2013) nudges me to consider these injustices; epistemic injustices are not just social, but also, within this ontoepisteme, are quiet moments. Children are not listened to because of their very being (onto-): a child is unable to make claims to knowledge, because it is "assumed that they are (still) developing, (still) innocent, (still) fragile, (still) immature, (still) irrational" (Murris, 2018, p. 2), (still) becoming, (still) monsters. Did I say children are monsters? No, it is the mutated irradiated microbiomes that inhabit the deep corners of their porous beings that I am afraid of. Who are these entangled monstrous beings?

Walking-with children is to walk with those who are deemed unworthy of recognition and are invisible in the anthro-obscene manifestations of western capitalism. Here is to walk into the past with ghosts and to share the horrors of a dystopian future. Hide it, don't show the world, this never happened. The practice of walking-with the past, present and future is to recognise the complexity of Barad's spacetimemattering. An entangled set of possibilities 
are revealed through the invoking of an alternative set of stories conjured up with children through being-in-place with a host of other re-configuring relations. Are you still walkingwith me? Who are you, adult researcher body from across the oceans, claiming to know how it feels to be an earthchild body, to be a container for generations of radiation trauma?

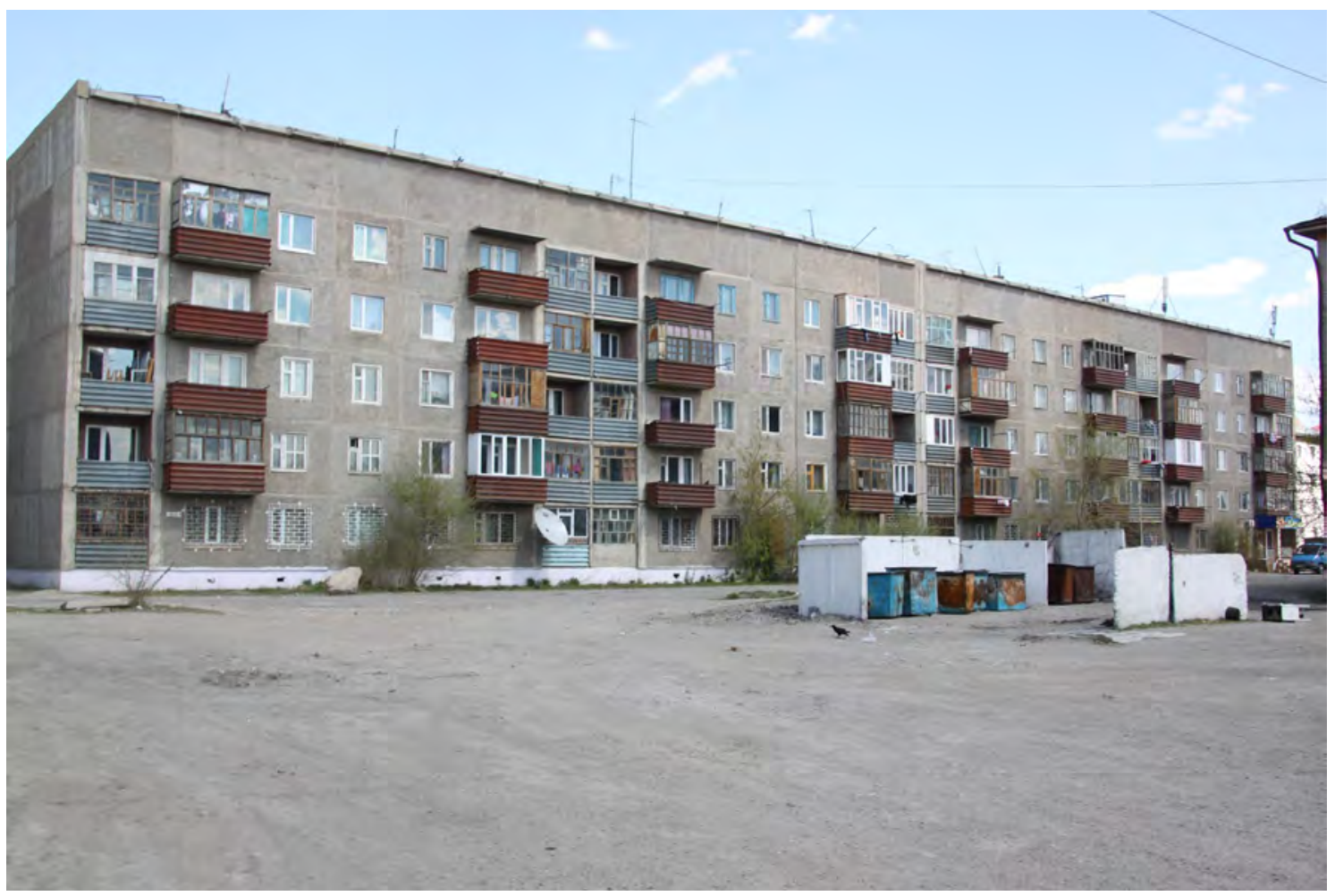

Figure 3: Apartment blocks. Photo credit: Author.

As with the sufferings of residents of the former plutonium-manufacturing districts of Russia, Australia and the USA-where radioactive traces still course through soil and water bodies - the porous bodies of the children I am walking-with in Semipalatinsk are suffused with illness and unease. Childbodies medicalised, labelled, scanned, and cleared of traces relating to illnesses from the past plutonium exposure. But deep beneath the surface, chronic doses of radiation are stimulating bacterial mutations. It seems many children suffer from the ills of their monstrous sympoietic relations with disrupted microbial companions (Haraway, 2017; McFall-Ngai, 2017). Monsters are the wonders of sympoiesis, threats of ecological disruption, virulent new pathogens to out-of-control chemical processes.

Children walking-with "symbiotic relations must be constantly renewed and negotiated within life's entanglements. When conditions suddenly shift, once life-sustaining relations sometimes turn deadly" (Tsing et al., 2017, M5). Donna whispers to me: 'to be one is always to become with many' (Haraway, 2016). "Symbioses are vulnerable; the fate of one species changes a whole ecosystem" (Tsing et al., 2017, M5). 


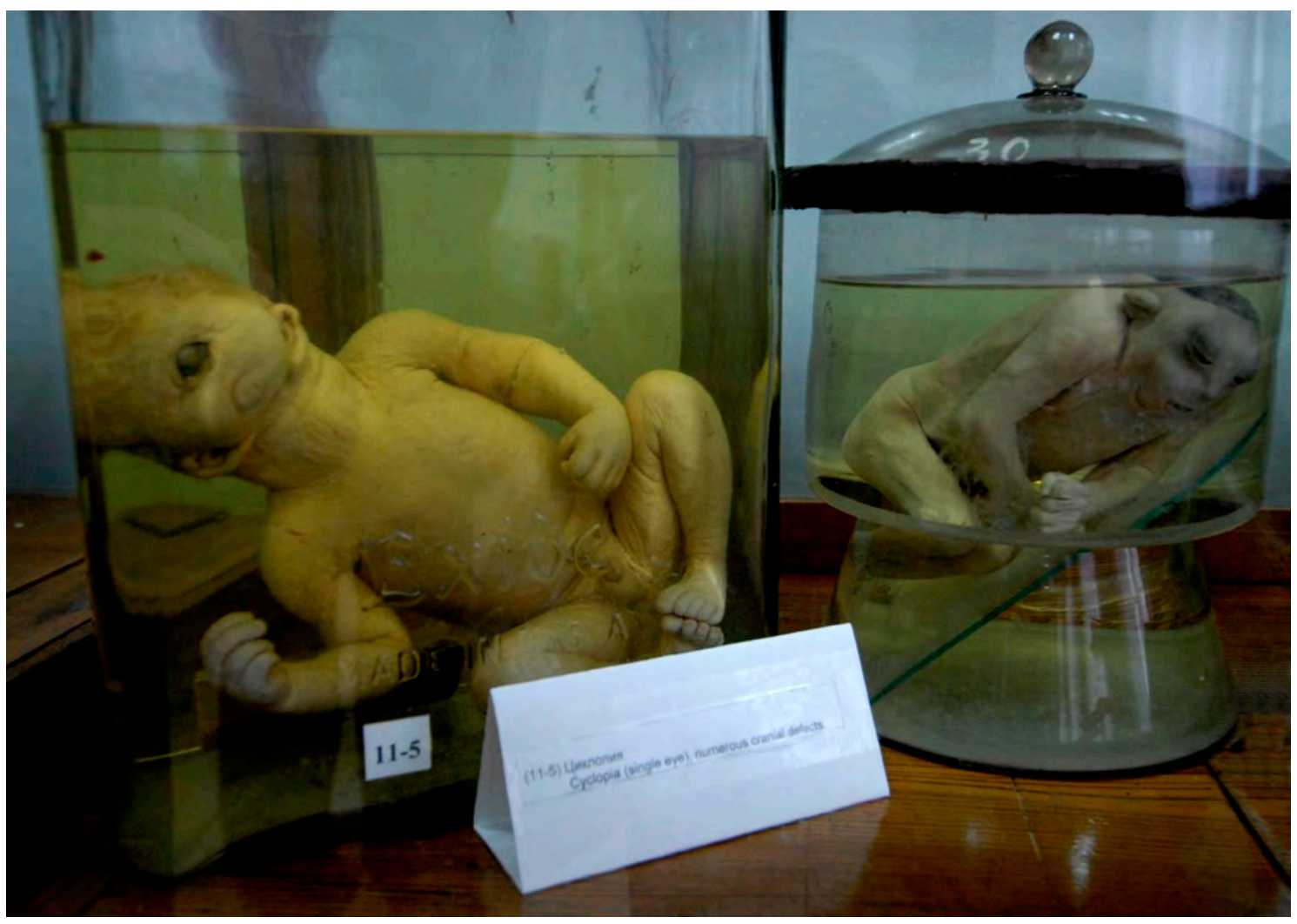

Figure 4: Monstrous bodies. Photo credit: Photographer John Van Hasselt-Corbis (Getty Images). Reprinted with permission.

Jars of deformed dead bodies are contained in a local museum. The children of our study tell me they have seen these 'bodies' penetrated by monstrous matter. Like the tumorous dogs we see while walking, these silenced bodies floating in fluid over time "provoke fear, but also fascination, as their ghostly presence, same but not quite, threatens to re-position or even to dissolve the boundaries of 'normality"' (Goodley, Runswick-Cole \& Liddiard, 2016, p. 772).

The killing of 'monstrous' babies born with 'deformities' has been traced back as far as the time of Aristotle... In more recent times, monstrosity was the justification for the 'euthanasia programmes' that systematically killed hundreds of thousands of disabled children[.] (Goodley et al., 2016, p. 771)

In these precarious times, it continues to be important to consider an approach that seeks to de-centre the human: to be attentive to the re-doing of material configurations and spacetimemattering. The past, the present and the future are always being reworked. This is ethical work (Barad, interviewed in Dolphijn, \& van der Tuin, 2012). Feminist new materialist models, like the ones described by Barad, replace an understanding of human subjectivity as neatly bordered, situated within (but distinct from) an environment-with a porous subjectivity that is materially co-constitutive of the environment. While Barad's agential realism asserts that “... questions of ethics and of justice are always already threaded through the very fabric of the world. They are not an additional concern that gets added on or placed in our field of vision now and again by particular kinds of concern" (Barad, interviewed in Dolphijn $\&$ van der Tuin, 2012, p. 69). Walking-with the children is always already entangled with a question of ethics. Equally important, our walking bears witness to the Anthropocene. In telling stories that matter, walking and writing in this paper are an act of witnessing: bringing attention to the unseen to tell stories that "awaken ethical sensibility" (Rose, 2012, p. 139) 
at this time of rapid unstoppable change. Is there any point in telling these stories? Stories of fear and ruin, causing grief and angst? Rose (2012) warns of a more prevailing dread "if no stories are told, if all the violence goes unremarked, then we are thrust into the world of the doubly violated. Silence, however comfortable it seems at times, is a failure to acknowledge the gravity of violence" (p. 139).

As I am walking-with children, we bear witness to lively matters of the Anthropocene:

"We are afraid of the street dogs. Dead dogs stink." Deformed babies, deformed dogs; Dead dogs' dead babies. "Do you know about the nuclear tests?" they ask as we walk. "Yes," I say, "I do know." "It is inside us," one child remarks. "It is probably in you now."

I blow my nose, we walk on.

\section{References}

Barad, K. (2017a). No small matter: Mushroom clouds, ecologies of nothingness, and strange topologies of spacetimemattering. In A. Tsing, H. Swanson, E. Gans, and N. Bubandt (Eds.), Arts of Living on a Damaged Planet (pp. G103-M120). Minneapolis, MN: University of Minnesota Press.

Barad, K. (2017b). Troubling time/s and ecologies of nothingness: Re-turning, remembering, and facing the incalculable. New Formations, 92, 56-86. https://doi.org/10.3898/NEWF:92.05.2017

Dolphijn, R., \& van der Tuin, I. (2012). "Matter feels, converses, suffers, desires, yearns and remembers": Interview with Karen Barad. In R. Dolphijn, and I. van der Turin (Eds.), New materialism: Interviews \& cartographies (pp. 48-70). London, UK: Open Humanities Press.

Dooren, T. V., \& Rose, D. B. (2016). Lively ethography: Storying animist worlds. Environmental Humanities, 8(1), 77-94. https://doi.org/10.1215/22011919-3527731

Goodley, D., Runswick-Cole, K., \& Liddiard, K. (2016). The DisHuman child. Discourse: Studies in the Cultural Politics of Education, 37(5), 770-784. https://doi.org/10.1080/01596306.2015.1075731.

Haraway, D. (2016). Staying with the trouble: Making kin in the chthulucene. Durham, NC: Duke University Press.

Haraway, D. (2017). Symbiogenesis, sympoiesis, and art science activisms for staying with the trouble. In A. Tsing, H. Swanson, E. Gans, \& N. Bubandt (Eds.), Arts of Living on a Damaged Planet (pp. M25-M50). Minneapolis, MN: University of Minnesota Press.

Malone, K. (2018). Children in the anthropocene. London, UK: Palgrave.

McFall-Ngai, M. (2017), Noticing microbial worlds: The postmodern synthesis in biology. In A. Tsing, H. Swanson, E. Gans, \& N. Bubandt (Eds.), Arts of Living on a Damaged Planet (pp. M51-M70). Minneapolis, MN: University of Minnesota Press.

Murris, K. (2013) The epistemic challenge of hearing children's voices. Studies in Philosophy and Education, 32(3), 245-259. https://doi.org/10.1007/s11217-012-9349-9 
Murris, K. (2018). Posthuman child and diffractive teacher: Decolonizing the nature/culture binary. In A. Cutter-Mackenzie, K. Malone, \& E. Barratt Hacking (Eds.), Research Handbook on Childhoodnature. Springer International Handbooks of Education. Springer, Cham.

Rose, D. B. (2012). Multispecies knots of ethical time. Environmental Philosophy, 9(1), 127-140. doi:10.5840/envirophil2012918

Sandlin, J. A., O'Malley, M. P., \& Burdick, J. (2011). Mapping the complexity of public pedagogy scholarship: 1894-2010. Review of Educational Research, 81(3), 338-375. https://doi.org/10.3102\%2F0034654311413395

Springgay, S., \& Truman, S. E. (2018). Walking methodologies in a more-than-human world: WalkingLab. New York, NY: Routledge.

Springgay, S., \& Truman, S. E. (2017). A transmaterial approach to walking methodologies: Embodiment, affect and a sonic art performance. Body \& Society, 23(4), 27-58. https://doi.org/10.1177/1357034X17732626

Tsing, A., Swanson, H., Gans, E., \& Bubandt, N. (Eds.) (2017). Arts of Living on a Damaged Planet. Minneapolis, MN: University of Minnesota Press.

Wuthnow, J. (2002). Deleuze in the postcolonial: On nomads and indigenous politics. Feminist Theory, 3(2), 183-200. https://doi.org/10.1177\%2F1464700102003002344

Dr. Karen Malone is Professor of Education and Research Director of the Department of Education, Faculty of Health, Arts and Design at Swinburne University of Technology in Melbourne. Professor Malone researches in urban ecologies, ecofeminism, and posthuman childhoods. Her global research program, Children in the Anthropocene, engages with postqualitative research with young children and their families in a variety of geographically diverse, precarious ecological locations. During her career, Malone has authored 7 books and over 100 publications. Her most recent sole-authored book, Children in the Anthropocene, was published in early 2018 and explores entangled child/hoods in the messy urban ecologies of Bolivia, Kazakhstan and Japan. She is co-author of the International Research Handbook on Childhoodnature, first named editor of the book series Children: Global Posthumanist perspectives and materialist theories and the edited collection Reimaginging Sustainability in Precarious Times. You can follow her work on: www.childrenintheanthropocene.com 